\title{
THE LABORATORY DIAGNOSIS OF LYMPHOGRANULOMA VENEREUM
}

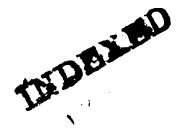

\author{
BY \\ S. P. BEDSON, C. F. BARWELL, E. J. KING, AND L. W. J. BISHOP \\ From the Department of Bacteriology, London Hospital Medical College
}

(RECEIVED FOR PUblication, JULy 19, 1949)

Although the literature on this subject is already quite considerable there is still some doubt as to the exact value of the different laboratory procedures available for the diagnosis of lymphogranuloma venereum. This does not, of course, apply to the demonstration of lymphogranuloma venereum virus in material from a suspected case of this disease, for this, as in any infective process, is of unequivocal value. Unfortunately the isolation and identification of lymphogranuloma venereum virus, though always worth undertaking, particularly in the early stages of the disease, is time-consuming and, in our limited experience, not nearly so readily achieved as some other workers have found (Wall, 1946). In the work here reported we have been more concerned with those laboratory tests, the Frei test and the lymphogranuloma venereum complement fixation test, which are of easy application and give an answer in a relatively short time. Much of the earlier work with these tests was done before Rake and his colleagues (1941) had drawn attention to the close relationship which exists between the viruses of the psittacosis-lymphogranuloma group. The extensive sharing of antigens, which is one of the important features of this relationship, is responsible for a high degree of cross reaction in complement fixation tests made with these viruses and their antisera (Rake, Eaton, and Shaffer, 1941) reducing them to a group specificity. The consequences for the Frei test are similar; a positive reaction to this test as at present practised is not confined to lymphogranuloma venereum but can also occur in infections with viruses of the psittacosis group (Rake, Eaton, and Shaffer, 1941). And although some of the more recent work on the Frei test and the complement fixation test in lymphogranuloma venereum has been done with Rake's important findings in mind the precise value of these two tests in the diagnosis of lymphogranuloma venereum is still far from clear. It was in an endeavour to remedy this deficiency and to find out if it would be possible to devise intra- dermal and serological tests of greater specificity that the following investigations were made.

\section{The Complement Fixation Test}

Technique.-The antigen was prepared from the yolk sacs of eggs inoculated on the fifth day of incubation and taken down four to five days later. Yolk sacs were ground in Tenbroek tubes and

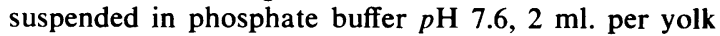
sac. After sedimentation in the refrigerator or a preliminary centrifugation to get rid of gross particles and of yolk, the partially clarified suspension was centrifuged for one and a half to two hours on an angle centrifuge at 5,000 revolutions per minute, the supernatant fluid discarded, and the deposit suspended to half volume in saline. A further period of sedimentation in the refrigerator for 24 to 48 hours resulted in the deposition of more extraneous material, which was discarded. If smears of this final suspension stained by Castaneda's method showed a satisfactory virus content, the suspension was steamed for 20 minutes, sodium azide added in a final concentration of $0.3 \%$ as preservative, and the antigen titrated with known lymphogranuloma venereum positive and negative sera. Such an antigen has rarely been found to be anticomplementary and it keeps its activity unchanged for at least several months. The use of phenol for enhancing antigenic activity, advocated by Nigg, Hilleman, and Bowser (1946), has not, in our hands, provided a better antigen than one prepared by the above method. One or two attempts to produce an antigen by the method of Smadel, Wertman, and Reagan (1943) were not sufficiently encouraging to induce us to adopt this more laborious method. The addition of formalin in $0.3 \%$ concentration in place of heat inactivation invariably made the antigen anticomplementary. A control antigen was prepared in a similar manner from normal yolk sacs of appropriate age.

Complement.-A satisfactory batch of guinea-pig serum was divided into quantities suitable for a day's test and stored in the dry ice-box. Retitration on the day of each test showed little or no change over 12 weeks. A dose of 2 M.H.D. was used.

The Test.-Falling doubling dilutions from 1 in 4 to 1 in 256 were prepared from the patients' sera which had been inactivated at $56^{\circ} \mathrm{C}$. for 30 minutes. 
Patients' serum, complement (2 M.H.D.), and antigen, $0.1 \mathrm{ml}$. of each, were added to tubes in this order and the volume in each tube made up to $0.8 \mathrm{ml}$. with saline. Each serum in highest concentration was put up with the control antigen and also without antigen to detect any anticomplementary activity ; other controls consisted of known positive and negative sera. Fixation was for 30 minutes at room temperature followed by 30 minutes in the $37^{\circ} \mathrm{C}$. water-bath. Sheep red cells with this disease are first seen in the secondary stage when the development of an inguinal adenitis has drawn attention to the presence of infection, and by that time antibody formation is usually well advanced. Other patients, and this is particularly true of women, only become aware of infection when the disease has reached the tertiary stage and some lesion, most usually in

TABLE I

Correlation between Clinical Diagnosis and Lymphogranuloma Venereum Complement Fixation Test

\begin{tabular}{c|c|c|c|c|c|c|c|c|c|c|c}
\hline $\begin{array}{c}\text { Clinical } \\
\text { Diagnosis of } \\
\text { Lymphogranuloma } \\
\text { Venereum }\end{array}$ & $\begin{array}{c}\text { Total } \\
\text { Number } \\
\text { of } \\
\text { Patients }\end{array}$ & \multicolumn{2}{|c|}{ Number of Cases giving Fixation with a Lymphogranuloma } \\
Venereum Antigen at Dilutions of & $\begin{array}{c}\text { Positive } \\
\text { Complement } \\
\text { Fixation Test } \\
\text { at 1/32 or } \\
\text { over (\%) }\end{array}$ \\
\hline Confident... & $\ldots$ & 32 & 0 & 0 & 0 & 4 & 7 & 11 & 10 & 0 & 87.5 \\
\hline Possible $\ldots$ & $\ldots$ & 31 & 7 & 1 & 6 & 10 & 2 & 3 & 2 & 0 & 22.6 \\
\hline Doubtful ... & $\ldots$ & 67 & 57 & 3 & 2 & 4 & 1 & 0 & 0 & 0 & $1 / 4$ \\
\hline
\end{tabular}

in 5\% suspension sensitized with 5 M.H.D. amboceptor were then added to each tube in $0.2 \mathrm{ml}$. quantities and the tubes returned to the $37^{\circ} \mathrm{C}$. water-bath for 30 minutes when the first reading was taken. A second reading was made after the tubes had stood at room temperature over night. The least dilution of serum giving complete fixation of 2 M.H.D. complement in the presence of antigen (no haemolysis at either the first or second reading) was taken as the titre. the rectum, draws attention to its presence. Only rarely is the disease seen early enough for the formation of antibodies to be followed, and reliance, therefore, has to be placed on a singles observation. Sera from 130 patients were exam? ined, the patients being divided into three groups according to whether the clinical diagnosis of lymphogranuloma venereum was confident, pos-

TABLE II

Comparison of Results of Complement Fixation Tests on Sera from Psittacosis and lymphogranuloma

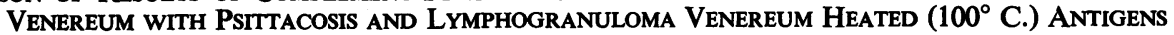

\begin{tabular}{ll|c|c|c|c}
\hline \multicolumn{2}{c|}{$\begin{array}{c}\text { Clinical } \\
\text { Diagnosis }\end{array}$} & $\begin{array}{c}\text { Number of } \\
\text { Sera Tested }\end{array}$ & $\begin{array}{c}\text { Same Titre with } \\
\text { Homologous and } \\
\text { Heterologous } \\
\text { Antigens }\end{array}$ & $\begin{array}{c}\text { Higher Titre with } \\
\text { Homologous } \\
\text { Antigen }\end{array}$ & $\begin{array}{c}\text { Higher Titre with } \\
\text { Heterologous } \\
\text { Antigen }\end{array}$ \\
\hline Lymphogranuloma & venereum & 19 & 16 & 3 & 0 \\
\hline Psittacosis $\ldots$ & $\ldots$ & $\ldots$ & 13 & 5 & 0
\end{tabular}

Diagnostic Value of a Single Complement Fixation Test.-An attempt was made first of all to determine the value of a single complement fixation test, and to this end the results of .this test made on a series of patients suspected of having lymphogranuloma venereum were compared with the clinical findings. When using the presence of antibody in a patient's serum as evidence of active infection the ideal undoubtedly is to demonstrate a significant rise in antibody titre, but this can only be done if the case is seen early enough and this rarely happens in lymphogranuloma venereum. The majority of patients sible, or doubtful. The results are recorded in Table I.

It will be seen that the serological findings show quite a close correlation with clinical diagnosis, and that in the "confident " group the majority of sera give titres of 1 in 32 or over, whereas in the "doubtful" group only one out of 67 sera comes in this high titre range and the majority had titres of less than 1 in 4 . In the clinically possible group greater. It seems justifiable to conclude from these findings that in a patient with symptoms compatible with a diagnosis of lymphogranuloma the titre scatter, as might be expected, was much 
venereum, a titre of 1 in 32 or over indicates active infection with lymphogranuloma venereum virus and that a titre of 1 in 16 is suggestive of this. Previous workers have reached much the same conclusion (Landau, 1946 ; Dulaney and Packer, 1947).

Attempts to Devise a More Specific Test.-In the complement fixation test as described above the effective antigen is the heat-stable one which is common to the viruses of the lymphogranuloma venereum-psittacosis group, and this means that the test would be positive in infections due to other members of the group. It is well recognized that this is so, and, as others have observed and we have amply confirmed in the course of this work, an antigen prepared from psittacosis virus in a similar manner could equally well be employed in the lymphogranuloma venereum complement fixation test. Smadel, Wertman, and Reagan (1943) state that, although this is so, sera from human cases of psittacosis give rather better fixation with the homologous antigen. This we can confirm. In Table II the results of complement fixation tests made with sera from cases of

TABLE III

Titration of Lymphogranuloma Venereum and Psittacosis Sera with Lymphogranuloma Venereum and PsitTacosis Virus Heated aNd UNHEATED

\begin{tabular}{|c|c|c|c|c|c|c|c|}
\hline \multicolumn{2}{|c|}{ Serum } & \multicolumn{2}{|c|}{$\begin{array}{l}\text { Lymphogranuloma } \\
\text { Venereum Virus }\end{array}$} & \multicolumn{2}{|c|}{ Psittacosis Virus } & \multirow{2}{*}{$\begin{array}{l}\text { Control } \\
\text { Antigen }\end{array}$} & \multirow{2}{*}{ Saline } \\
\hline $\begin{array}{c}\text { Clinical } \\
\text { Condition }\end{array}$ & Dilution & Unheated & $\begin{array}{l}\text { Heated } \\
\left(100^{\circ} \mathrm{C} .\right)\end{array}$ & Unheated & $\begin{array}{l}\text { Heated } \\
\left(100^{\circ} \mathrm{C} .\right)\end{array}$ & & \\
\hline \multirow[t]{4}{*}{$\begin{array}{l}\text { Lymphogranuloma } \\
\text { venereum "G" }\end{array}$} & $1 / 8$ & $\begin{array}{l}++++ \\
++++\end{array}$ & $\begin{array}{l}++++ \\
++++\end{array}$ & $\begin{array}{l}++++ \\
++++\end{array}$ & $\begin{array}{l}++++ \\
++++\end{array}$ & $\overline{-}$ & 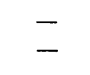 \\
\hline & $1 / 16$ & $\begin{array}{l}++++ \\
+++\end{array}$ & $\begin{array}{l}++++ \\
+++\end{array}$ & $\begin{array}{l}++++ \\
+++\end{array}$ & $\begin{array}{l}++++ \\
+++\end{array}$ & & \\
\hline & $1 / 32$ & $\begin{array}{l}++++ \\
+++t\end{array}$ & $\begin{array}{l}++++ \\
++++\end{array}$ & $\begin{array}{l}++++ \\
++++\end{array}$ & $\begin{array}{l}++++ \\
++++\end{array}$ & & \\
\hline & $1 / 64$ & $\begin{array}{l}++++ \\
+++\end{array}$ & $\begin{array}{l}++++ \\
+++\end{array}$ & $\begin{array}{l}++++ \\
+++\end{array}$ & $\begin{array}{l}++++ \\
+++\end{array}$ & & \\
\hline \multirow[t]{4}{*}{ Psittacosis “ Jo" ... } & $1 / 4$ & $\begin{array}{l}++++ \\
++++\end{array}$ & $\begin{array}{l}++++ \\
++++\end{array}$ & $\begin{array}{l}++++ \\
++++\end{array}$ & $\begin{array}{l}++++ \\
++++\end{array}$ & $\overline{-}$ & - \\
\hline & $1 / 8$ & $\begin{array}{l}++++ \\
+++\end{array}$ & $\begin{array}{l}++++ \\
++++\end{array}$ & $\begin{array}{l}++++ \\
\dot{1}+++\end{array}$ & $\begin{array}{l}++++ \\
++++\end{array}$ & & \\
\hline & $1 / 16$ & $\begin{array}{l}+++ \\
++\end{array}$ & $\begin{array}{l}++++ \\
++++\end{array}$ & $\begin{array}{l}++++ \\
++++\end{array}$ & $\begin{array}{l}++++ \\
++++\end{array}$ & & \\
\hline & $1 / 32$ & & $\begin{array}{l}+++ \\
+++\end{array}$ & $\begin{array}{l}++++ \\
+++\end{array}$ & $\begin{array}{l}++++ \\
+++\end{array}$ & & \\
\hline \multirow[t]{4}{*}{ Psittacosis “ $L " \quad \ldots$} & $1 / 8$ & $\begin{array}{l}++ \\
+\end{array}$ & $\begin{array}{l}++++ \\
++++\end{array}$ & $\begin{array}{l}++++ \\
++++\end{array}$ & $\begin{array}{l}++++ \\
++++\end{array}$ & $\overline{-}$ & $\begin{array}{l}- \\
-\end{array}$ \\
\hline & $1 / 16$ & $\overline{-}$ & $\begin{array}{l}++++ \\
+++\end{array}$ & $\begin{array}{l}++++ \\
+++\end{array}$ & $\begin{array}{l}++++ \\
+++\end{array}$ & & \\
\hline & $1 / 32$ & $\overline{-}$ & $\begin{array}{l}++++ \\
+++\end{array}$ & $\begin{array}{l}++++ \\
+++\end{array}$ & $\begin{array}{l}++++ \\
++++\end{array}$ & & \\
\hline & $1 / 64$ & - & $\begin{array}{l}++++ \\
+++\end{array}$ & $\begin{array}{l}+++ \\
+++\end{array}$ & $\begin{array}{l}++++ \\
+++\end{array}$ & & \\
\hline Normal $\quad \ldots$ & $1 / 4$ & $\overline{-}$ & $\begin{array}{l}- \\
-\end{array}$ & $\begin{array}{l}- \\
-\end{array}$ & - & - & $\overline{-}$ \\
\hline Saline $\quad \ldots$ & & $\overline{-}$ & $\overline{-}$ & $\overline{-}$ & $\overline{-}$ & $\overline{-}$ & $\overline{-}$ \\
\hline
\end{tabular}


lymphogranuloma venereum and psittacosis and the two heated antigens used in parallel show that sera from human cases of psittacosis do tend to give a higher titre with the steamed psittacosis virus than with the heterologous antigen, though why this should be is difficult to understand. However, the difference is neither great enough nor sufficiently constant to make it of use diagnostically.

It is known that psittacosis virus contains a heat-labile antigen in addition to the stable group specific one (Bedson, 1936 ; Barwell, 1948), and there is evidence that the viruses of the psittacosislymphogranuloma venereum group each possess a specific antigen (Hilleman and Gordon, 1944 ; Hilleman, 1945 ; St. John and Gordon, 1947) which can be detected by neutralization tests made with antisera produced in the domestic fowl. Neutralization tests made with human and mammalian sera give no such clear-cut specificity. Presumably the specific antigen is the labile component, and the superiority of the fowl sera in neutralizing is due to the better response in the bird to this antigen than occurs in man and mammals. Rake and Jones (1944) have also shown that these viruses, when grown in the yolk sac, produce $\overrightarrow{\text { s. }}$ species-specific labile toxins which are lethal to the mouse on intravenous inoculation, but the relationship of this work to that of Hilleman and $\overline{\bar{\omega}}$. his colleagues is not clear. However, there is $\overline{\mathrm{D}}$ evidence that mammalian anti-psittacosis sera do contain antibody to the labile antigen (Bedson, 1936), and it was thought that complement fixation $\overrightarrow{0}$ tests made with fresh unheated lymphogranuloma venereum virus might show greater specificity. Accordingly, sera from cases of lymphogranuloman venereum and human psittacosis were titrated against suspensions of both viruses unheated and heated at $100^{\circ} \mathrm{C}$. The results were disappointing. The majority of lymphogranuloma venereum sera showed little or no difference in titre with all fours antigens, though the psittacosis sera usually gave a lower titre-sometimes remarkably so-with theo unheated heterologous antigen. An extremex example of this is shown in Table III.

TABLE IV

Absorption of a Lymphogranuloma Venereum Serum with Steamed Psittacosis Virus

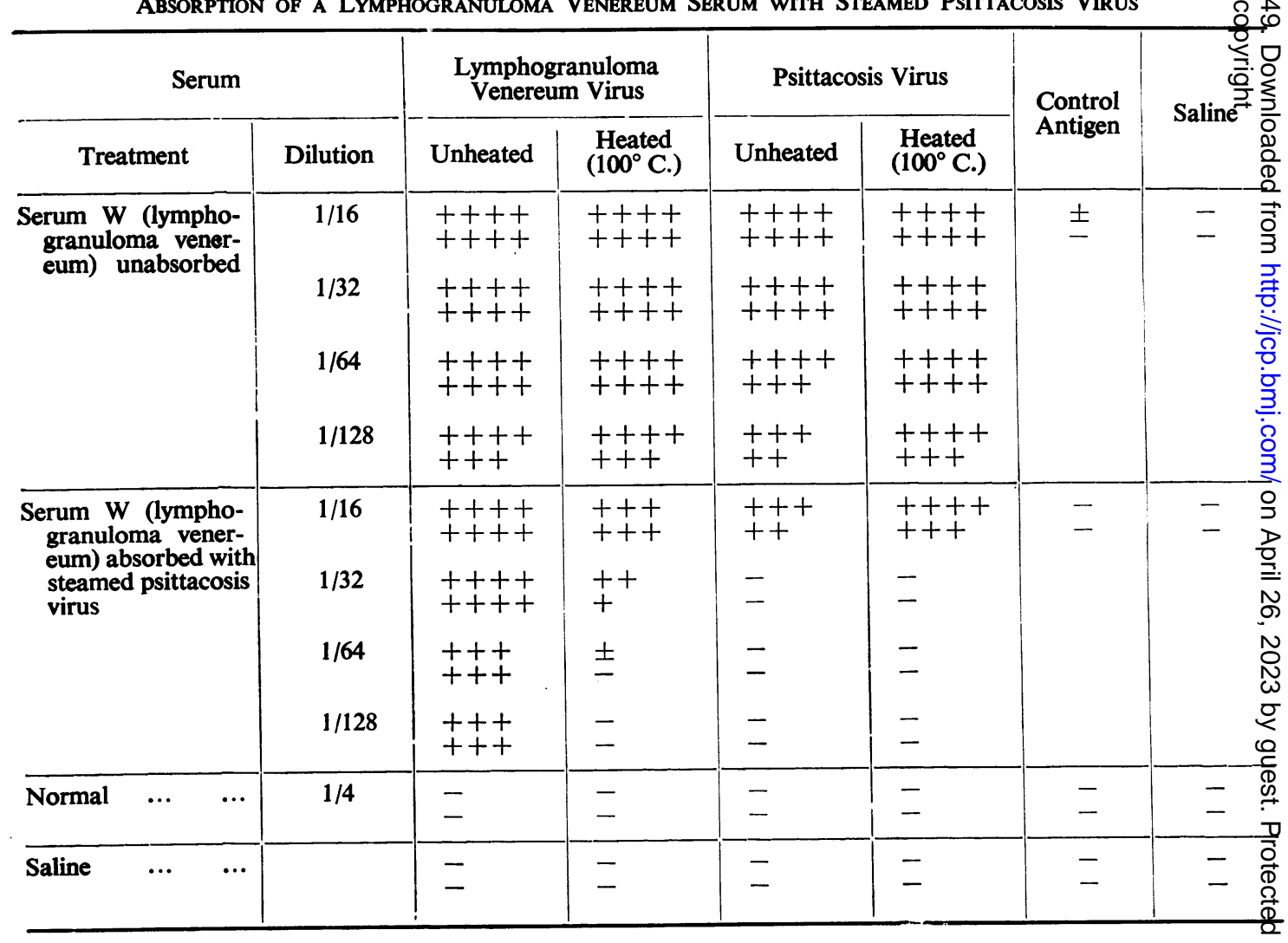


TABLE V

Absorption of a Lymphogranuloma Venereum Serum with Steamed lymphogranuloma Venereum Virus

\begin{tabular}{|c|c|c|c|c|c|c|c|}
\hline \multicolumn{2}{|l|}{ Serum } & \multicolumn{2}{|c|}{$\begin{array}{l}\text { Lymphogranuloma } \\
\text { Venereum Virus }\end{array}$} & \multicolumn{2}{|c|}{ Psittacosis Virus } & \multirow{2}{*}{$\begin{array}{l}\text { Control } \\
\text { Antigen }\end{array}$} & \multirow{2}{*}{ Saline } \\
\hline Treatment & Dilution & Unheated & $\begin{array}{l}\text { Heated } \\
\left(100^{\circ} \mathrm{C} .\right)\end{array}$ & Unheated & $\begin{array}{l}\text { Heated } \\
\left(100^{\circ} \mathrm{C} .\right)\end{array}$ & & \\
\hline \multirow{4}{*}{$\begin{array}{l}\text { Serum P. (lympho- } \\
\text { granuloma vener- } \\
\text { eum) unabsorbed }\end{array}$} & $1 / 16$ & $\begin{array}{l}++++ \\
++++\end{array}$ & $\begin{array}{l}++++ \\
++++\end{array}$ & $\begin{array}{l}++++ \\
++++\end{array}$ & $\begin{array}{l}++++ \\
++++\end{array}$ & - & - \\
\hline & $1 / 32$ & $\begin{array}{l}++++ \\
++++\end{array}$ & $\begin{array}{l}++++ \\
++++\end{array}$ & $\begin{array}{l}++++ \\
+++\end{array}$ & $\begin{array}{l}++++ \\
++++\end{array}$ & & \\
\hline & $1 / 64$ & $\begin{array}{l}++++ \\
+++t\end{array}$ & $\begin{array}{l}+++ \\
++++\end{array}$ & $\begin{array}{l}+++ \\
++\end{array}$ & $\begin{array}{l}++++ \\
++++\end{array}$ & & \\
\hline & $1 / 128$ & $\begin{array}{l}+++ \\
+++\end{array}$ & $\begin{array}{l}++++ \\
+++\end{array}$ & $\begin{array}{l}- \\
-\end{array}$ & $\begin{array}{l}+++ \\
+++\end{array}$ & & \\
\hline \multirow{4}{*}{$\begin{array}{l}\text { Serum P. (lympho- } \\
\text { granuloma vener- } \\
\text { eum) absorbed with } \\
\text { steamed lympho- } \\
\text { granuloma vener- } \\
\text { eum virus }\end{array}$} & $1 / 16$ & $\begin{array}{l}+++t \\
+++t\end{array}$ & $\begin{array}{l}+ \\
\pm\end{array}$ & $\begin{array}{l}++ \\
+\end{array}$ & $\begin{array}{l}+ \\
\pm\end{array}$ & \pm & - \\
\hline & $1 / 32$ & $\begin{array}{l}++++ \\
++++\end{array}$ & $\overline{-}$ & - & $\overline{-}$ & & \\
\hline & $1 / 64$ & $\begin{array}{l}++ \\
+\end{array}$ & - & - & $\overline{-}$ & & \\
\hline & $1 / 128$ & $\overline{-}$ & - & 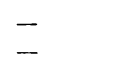 & - & & \\
\hline Normal & $1 / 4$ & $\overline{-}$ & $\begin{array}{l}- \\
-\end{array}$ & $\overline{-}$ & $\overline{-}$ & - & - \\
\hline Saline $\quad \cdots \quad \ldots$ & & - & - & - & $\overline{-}$ & $\overline{-}$ & $\begin{array}{l}- \\
-\end{array}$ \\
\hline
\end{tabular}

It has been shown that if a psittacosis antiserum made in the guinea-pig is absorbed with steamed psittacosis virus the corresponding antibody is removed, leaving the antibody to the labile antigen more or less unchanged, whereas absorption with the unheated virus removed both (Bedson, 1936). It was thought, therefore, that absorption of human lymphogranuloma venereum sera with steamed virus ought to remove their ability to react not only with the steamed homologous virus but also with both forms of heterologous virus, leaving them to react in an entirely specific manner. It was argued that the reaction with the unheated heterologous virus was apparent only and due to the heat-stable group antigen even in the unheated virus being available for reaction with the group antibody. Theoretically, either steamed psittacosis or lymphogranuloma venereum virus could be used for the absorption, and this, in fact, proved to be so.

\section{Absorption Test}

Psittacosis or lymphogranuloma venereum virus, prepared as already described (partially purified and steamed), was deposited from suspension by centrifugation for one hour on an angle centrifuge at 3,000 r.p.m., the supernatant discarded, and the deposit resuspended in the serum to be absorbed, suitably diluted. A concentration of eight times the titre was found satisfactory. Absorption was allowed to continue overnight in the refrigerator, when the virus was removed by thorough centrifugation (two hours on an angle centrifuge at 5,000 r.p.m.). The absorbed serum was then titrated against all four antigens, heterologous and homologous heated and unheated, in parallel with the unabsorbed serum.

Absorption with the control antigen was shown to have no effect on the antibody content of the serum. The results obtained in the absorption of two lymphogranuloma venereum sera, one with steamed heterologous virus and the other with the homologous preparation, are recorded in Tables IV and $\mathrm{V}$. 
In both cases the absorption has removed, or very considerably reduced, the ability of the serum to react with the heterologous virus heated or unheated, as well as with the heated homologous antigen, and left the major part of the antibody for the unheated homologous virus; the test has been made specific. That this in fact is so is shown by the experiment recorded in Table VI, where the serum from a case of psittacosis has been absorbed with steamed virus; again the test becomes specific.

Admittedly the procedure is laborious, and it is not suggested that it should be adopted as a routine in the serological diagnosis of lymphogranuloma venereum. It is, however, available in those cases where doubt exists.

\section{The Frei Test}

In the Frei test, as in the complement fixation test $\stackrel{\text { ․ }}{\rightarrow}$ as usually done, the effective antigen is the heat-stable $\overrightarrow{\vec{F}}$ group antigen; at any rate that is true of the routine $-\overrightarrow{0}$ Frei test made by us, in which the steamed lymphogranuloma venereum virus as used in the complement $\frac{\bar{\sigma}}{\bar{\omega}}$. fixation test, but without any added antiseptic, has $\vec{\sigma}$ been employed. The antigen was used in double the $\varrho$ dilution effective in the complement fixation test; the cose employed was $0.1 \mathrm{ml}$. Readings were made at two and four or five days. The size of nodule pro- $\odot$ duced was measured, and anything less than $0.5 \mathrm{~cm} . \overrightarrow{\vec{\omega}}$ at the second reading was regarded as negative; the extent of erythema was ignored.

The great majority of patients examined serologically were also submitted to the Frei test, and + in recording the results of this test in Table VII

TABLE VI

Absorption of a Psittacosis Serum with Steamed Psittacosis Virus

\begin{tabular}{|c|c|c|c|c|c|c|c|}
\hline \multicolumn{2}{|l|}{ Serum } & \multicolumn{2}{|c|}{ Psittacosis Virus } & \multicolumn{2}{|c|}{$\begin{array}{l}\text { Lymphogranuloma } \\
\text { Venereum Virus }\end{array}$} & \multirow{2}{*}{$\begin{array}{l}\text { Control } \\
\text { Antigen }\end{array}$} & \multirow{2}{*}{ Saline $\frac{\stackrel{\frac{\sigma}{\Phi}}{\frac{c}{0}}}{8}$} \\
\hline Treatment & Dilution & Unheated & $\begin{array}{l}\text { Heated } \\
\left(100^{\circ} \mathrm{C} .\right)\end{array}$ & Unheated & $\begin{array}{l}\text { Heated } \\
\left(100^{\circ} \mathrm{C} .\right)\end{array}$ & & \\
\hline \multirow[t]{5}{*}{$\begin{array}{l}\text { Serum M. (psittaco- } \\
\text { sis) unabsorbed }\end{array}$} & $1 / 16$ & $\begin{array}{l}++++ \\
++++\end{array}$ & $\begin{array}{l}++++ \\
++++\end{array}$ & $\begin{array}{l}++++ \\
++++\end{array}$ & $\begin{array}{l}++++ \\
++++\end{array}$ & $\begin{array}{l}- \\
-\end{array}$ & 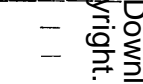 \\
\hline & $1 / 32$ & $\begin{array}{l}++++ \\
++++\end{array}$ & $\begin{array}{l}++++ \\
++++\end{array}$ & $\begin{array}{l}++++ \\
++++\end{array}$ & $\begin{array}{l}++++ \\
++++\end{array}$ & & ڤั) \\
\hline & $1 / 64$ & $\begin{array}{l}++++ \\
+++\end{array}$ & $\begin{array}{l}++++ \\
+++\end{array}$ & $\begin{array}{l}++++ \\
+++\end{array}$ & $\begin{array}{l}++++ \\
+++\end{array}$ & & $\frac{\vec{F}}{3}$ \\
\hline & $1 / 128$ & $\begin{array}{l}++++ \\
+++\end{array}$ & $\begin{array}{l}++++ \\
++++\end{array}$ & $\begin{array}{l}+++ \\
++\end{array}$ & $\begin{array}{l}++++ \\
+++\end{array}$ & & 点 \\
\hline & $1 / 256$ & $\begin{array}{l}+++ \\
++\end{array}$ & $\begin{array}{l}++++ \\
+++\end{array}$ & $\begin{array}{l}++ \\
+\end{array}$ & $\begin{array}{l}++ \\
+\end{array}$ & & $\frac{7}{3}$ \\
\hline \multirow{5}{*}{$\begin{array}{l}\text { Serum M. (psittaco- } \\
\text { sis) absorbed with } \\
\text { steamed psittaco- } \\
\text { sis virus }\end{array}$} & & $\begin{array}{l}++++ \\
++++\end{array}$ & $\begin{array}{l}++++ \\
+++\end{array}$ & $\begin{array}{l}++++ \\
+++\end{array}$ & $\begin{array}{l}+++ \\
++\end{array}$ & $\begin{array}{l}+ \\
+\end{array}$ & $\begin{array}{l}+ \\
\pm\end{array}$ \\
\hline & $1 / 32$ & $\begin{array}{l}++++ \\
++++\end{array}$ & $\begin{array}{l}+++ \\
++\end{array}$ & $\begin{array}{l}++ \\
+\end{array}$ & + & & \\
\hline & $1 / 64$ & $\begin{array}{l}++++ \\
+++\end{array}$ & $\begin{array}{l}+ \\
\pm\end{array}$ & $\stackrel{ \pm}{\neq}$ & - & & \\
\hline & $1 / 128$ & $\begin{array}{l}++++ \\
+++\end{array}$ & $\stackrel{ \pm}{\mp}$ & - & $\overline{-}$ & & \\
\hline & $1 / 256$ & $\begin{array}{l}+++ \\
++\end{array}$ & $\overline{-}$ & - & - & & 0 \\
\hline $\begin{array}{lll}\text { Normal } & \ldots & \ldots\end{array}$ & $1 / 4$ & $\overline{-}$ & $\overline{-}$ & $\underline{-}$ & $\overline{-}$ & $\overline{-}$ & $\overline{-}$ \\
\hline Saline $\quad \ldots$ & & - & $\overline{-}$ & $\overline{-}$ & - & $\overline{-}$ & $\begin{array}{l}- \\
-\end{array}$ \\
\hline
\end{tabular}


TABLE VII

Correlation between Frei Test, Lymphogranuloma Venereum Complement Fixation Test, and Clinical DIAGNOSIS

\begin{tabular}{|c|c|c|c|c|c|c|c|c|c|c|}
\hline \multirow{2}{*}{\multicolumn{3}{|c|}{$\begin{array}{c}\text { Clinical Diagnosis of } \\
\text { Lymphogranuloma } \\
\text { Venereum }\end{array}$}} & \multirow{2}{*}{$\begin{array}{l}\text { Number } \\
\text { of } \\
\text { Patients }\end{array}$} & \multicolumn{7}{|c|}{ Lymphogranuloma Venereum Complement Fixation Titre } \\
\hline & & & & $<1 / 4$ & $1 / 4$ & $1 / 8$ & $1 / 16$ & $1 / 32$ & $1 / 64$ & $1 / 128$ \\
\hline Confident & $\ldots$ & $\ldots$ & 28 & $0 / 0^{*}$ & $0 / 0$ & $0 / 0$ & $4 / 4$ & $4 / 4$ & $11 / 11$ & $9 / 9$ \\
\hline Possible & $\ldots$ & $\ldots$ & 25 & $6 / 7$ & $0 / 1$ & $3 / 4$ & $6 / 7$ & $2 / 2$ & $2 / 2$ & $2 / 2$ \\
\hline Doubtful & $\ldots$ & $\ldots$ & 59 & $3 / 49$ & $1 / 3$ & $0 / 2$ & $0 / 4$ & $1 / 1$ & $0 / 0$ & $0 / 0$ \\
\hline
\end{tabular}

* Numerator gives the number of positive reactors and the denominator the number of patients tested.

an attempt has been made to show the relationship of the Frei test with the clinical and serological findings.

Two things strike one about these results. The first is the close parallelism between the Frei test and the complement fixation test in the clinically acceptable group, and the second is the number of patients suspected possibly of having lymphogranuloma venereum who have a strongly positive Frei reaction but little or no antibody in their blood. It is well known that the Frei test may remain positive long after clinical cure, whereas one would expect the antibody titre to fall when the infection became quiescent ; whether infection is ever eradicated or how often this occurs it is impossible to say. It seems, therefore, that those patients with a positive Frei test and little or no antibody are old cases of lymphogranuloma venereum in which the disease is now quiescent. And since the effective antigen in the Frei test material is the group antigen it follows that a positive reaction by itself does no more than indicate that infection with a virus of the psittacosis lymphogranuloma venereum group has occurred, but whether recently or not only the additional evidence supplied by the complement fixation test can tell us. The two tests should be used concurrently, and it seems justifiable to conclude that in a patient with symptoms at all suggestive of lymphogranuloma venereum a positive Frei test with a complement fixation titre of 1 in 16 or over indicates an active infection with this virus. In the clinically doubtful group there is one result which is out of keeping, that of a patient in whom the Frei test was positive and whose serum gave a titre of 1 in 32. This patient, a man, was first seen when he had a urethritis of one month's duration. The discharge was muco-purulent and, both microscopically and culturally, was free of pathogenic micro-organisms. He was married. No clinical or laboratory evidence of lymphogranuloma venereum infection was found in his wife, and he denied extramarital venereal exposure. The Frei test made when the patient was first seen was doubtful, but when repeated three weeks later had become strongly positive. The complement fixation test on the first occasion gave a titre of 1 in 8 which rose to 1 in 32 three weeks later and, when tested after a further interval of a month, had fallen to 1 in 8 . Treatment consisted of irrigation only, and the response was so satisfactory that when the third specimen of serum was collected he was clinically well. The results of the Frei test and the complement fixation test both suggest active lymphogranuloma venereum infection, and it is said that a primary lymphogranuloma venereum lesion in the anterior part of the urethra may produce symptoms of a nonspecific urethritis. What is surprising is the transient nature of the infection, and this raises the question as to whether or not this may not have been infection with the related virus of inclusion blenorrhoea. An absorption test on the second specimen of serum might have settled this point ; unfortunately, there was insufficient of this pertinent specimen on which to do the test.

\section{Intradermal Reactions with Psittacosis Virus}

Reference has been made to the fact that the Frei test may be positive in psittacosis infections (Rake, Eaton, and Shaffer, 1941), but with the exception of some observations of Pollard and Witka (1947) intradermal tests with psittacosis virus in patients with lymphogranuloma venereum do not seem to have been made. Using steamed virus for this purpose the same result as with steamed lymphogranuloma venereum virus might be expected, since the effective antigen in both would be the group antigen. Parallel intradermal tests with steamed lymphogranuloma venereum 
TABLE VIII

Intradermal Tests with Psittacosis Virus in Patients Suspected of having Lymphogranuloma Venereum

\begin{tabular}{c|c|c|c|c|c}
\hline $\begin{array}{c}\text { Clinical Appraisal of } \\
\text { Condition and by } \\
\text { Complement Fixation Test }\end{array}$ & $\begin{array}{c}\text { Number } \\
\text { of } \\
\text { Cases }\end{array}$ & \multicolumn{2}{|c|}{ Intradermal Tests with Steamed Psittacosis and Lymphogranuloma } \\
Venereum Virus
\end{tabular}

and psittacosis viruses have been made in 39 patients suspected on clinical grounds of having lymphogranuloma venereum. The conditions of the test were as in the Frei test described above, and only induration of $0.5 \mathrm{~cm}$. or more was considered positive. The results, which are given in Table VIII, show considerable concordance. The three patients with a positive reaction to lymphogranuloma venereum virus and a negative one to psittacosis all showed some reaction to the psittacosis antigen, but since the induration was less than $0.5 \mathrm{~cm}$. it was recorded as negative; the reactions were $0.3 \mathrm{~cm} ., 0.3 \mathrm{~cm}$., and $0.4 \mathrm{~cm}$. None gave any reaction with the control (normal yolk sac) antigen ; in fact, only one egg-sensitive patient has been encountered in this work.

\section{Attempts to Produce a Specific Skin Test Antigen}

Experiments in which psittacosis virus from mouse spleen was tested by complement fixation after treatment with various reagents (Barwell, 1948) had shown that high dilutions of potassium periodate readily inactivated the heat-stable group antigen: fresh unheated virus suspensions, treated in the same way, still reacted with sera containing specific antibody. It was thought that this might provide a means of removing the group reactivity of skin test antigens. Preliminary tests with heated lymphogranuloma venereum virus showed, however, that reactions equal to those given by control antigens were obtained after treatment with 0.04 Molar $\mathrm{KIO}_{1}$ - that is, at least ten times the concentration required to remove complement fixing ability. This difference might be due to the fact that only a small proportion of group antigen is destroyed in the virus particle by periodate.

The earlier serological studies had also shown that dilute acids, like heat, yielded elementary body suspensions which reacted as the group antigen. This suggested that the specific component might be carried into solution in the presence of acid ; it was not possible, however, to demonstrate by complement fixation any activity in such extracts after they had been freed from virus particles. The possibility that solutions made in the same way might react specifically in the skin of infected patients was then investigated.

Technique.-Partially purified yolk sac suspensions of psittacosis and lymphogranuloma venereum viruses were made in saline from recently harvested material ; $0.1 \mathrm{~N} . \mathrm{HCl}$ was then added to give a final concentration of 0.02 Normal. The $p \mathbf{H}$ of the mixture was between 3.0 and 4.0 and an immediate clearing was usually obvious. The tubes were placed at $37^{\circ} \mathrm{C}$. foro 15 minutes and then spun on angle centrifuge a 4,000 r.p.m. for one and a half hours. The slightly opalescent supernatant fluid was removed and its $p \mathrm{H}$ adjusted to 7.4-7.6 with $\mathrm{NaOH}$. A white or pale yellow precipitate began to form at a $p \mathrm{H}$ of about 5 , and became floccular and usually copious as neutralization proceeded. It was removed by centrifugation. A single skin test failed to reveal any activity in this material. The clear supernatant fluids (acid extracts) were used undiluted as skin test antigens. The method was that described above for the Frei test.

Only a small number of patients has so far been available for this trial; the results obtained with five cases of lymphogranuloma venereum and with one of psittacosis are shown in Table IX, in which are recorded the reactions to extracts of the two viruses as well as to the heated, diluted suspensions. It will be seen that the acid-soluble antigen of psittacosis virus fails to produce a reaction in the cases of lymphogranuloma venereum ; in each of them, however, the homologous extract elicits a definite response. In the one case of psittacosis the results of using these preparations were equally specific. Patients with lymphogranuloma venereum are again show $n$ to react to heated suspensions of psittacosis virus, but it was not possible to demonstrate activity of a heated suspension of lymphogranuloma venereum virus in the patient who had recovered from psittacosis. 
TABLE IX

Analysis of Results of Skin Tests and Reactions to Lymphogranuloma Venereum and Psittacosis Viruses

\begin{tabular}{l|l|c|c|c|c|c|c}
\hline & \multicolumn{1}{|c|}{$\begin{array}{c}\text { Comple- } \\
\text { ment } \\
\text { Patient }\end{array}$} & $\begin{array}{c}\text { Clinical Findings } \\
\text { Test } \\
\text { Titre }\end{array}$ & $\begin{array}{c}\text { Heated Suspensions } \\
\text { granpho- } \\
\text { Venereum }\end{array}$ & Psittacosis & $\begin{array}{c}\text { Normal } \\
\text { Yolk Sac }\end{array}$ & $\begin{array}{c}\text { Lympho- } \\
\text { granuloma } \\
\text { Venereum }\end{array}$ & Psittacosis \\
\hline T33986 & Inguinal adenitis 4 weeks & $1 / 64$ & $6 *$ & Not done & 0 & 25 & $<5$ \\
\hline T34684 & Penile sore 6 weeks & $1 / 16$ & 5 & 5 & 0 & 17 & 0 \\
\hline H7265 & Rectal stricture & $1 / 128$ & $\begin{array}{c}++ \\
\text { Slough 10 mm. }\end{array}$ & 12 & 0 & 20 & 0 \\
\hline H5779 & Proctitis & $1 / 32$ & 8 & 15 & 0 & 25 & 0 \\
\hline T8930 & $\begin{array}{l}\text { Penile ulcer 1 month's } \\
\text { duration }\end{array}$ & $1 / 16$ & 10 & 8 & 0 & 23 & 0 \\
\hline F.A.R. & $\begin{array}{l}\text { Psittacosis 6 months pre- } \\
\text { viously }\end{array}$ & $1 / 64$ & 0 & 20 & 0 & 0 & 15 \\
\hline
\end{tabular}

* Figures indicate the diameter in millimetres of the area of induration observed 2 days after intradermal inoculation.

\section{Summary}

Titres of 1 in 32 or over in the complement fixation test made with steamed lymphogranuioma venereum virus and the sera from patients in whom the clinical findings are compatib.e with a diagnosis of lymphogranuloma venereum suggest active infection with lymphogranuloma venereum virus.

As others have observed, the sera from human infections with psittacosis and lymphogranuloma venereum viruses show a very high degree of cross reaction in the complement fixation test with antigens made from these two viruses. These cross reactions occur to titre, or almost so, with antigens in which the heat-stable antigenic component is the effective one, but to a lesser degree, particularly in the case of psittacosis sera, with the fresh unheated viruses; this difference is insufficiently great or constant to be diagnostic. Sera from human infections with psittacosis and lymphogranuloma venereum viruses contain specific antibody which can be revealed by removing the group antibody by absorption with steamed virus whether homologous or heterologous.

The Frei test, as usually done, also merely indicates that infection with a virus of the lymphogranuloma venereum psittacosis group has occurred.

A positive Frei test, together with a positive complement fixation test at a serum dilution of 1 in 16 or over, in a patient suspected of having lymphogranuloma venereum is good evidence of active lymphogranuloma venereum infection. Acid extracts of lymphogranuloma venereum and psittacosis viruses appear to give specific reactions when injected intradermally in human infections with these two viruses.

We wish to express our indebtedness to Mr. A. J. King, Director of the Venereal Disease Department of the London Hospital, and his colleagues, Dr. F. Curtis and Dr. C. Nicol, for their co-operation in this investigation, as well as to the numerous doctors outside the London Hospital who supplied us with material and information.

\section{REFERENCES}

Barwell, C. F. (1948). Nature, Lond., 162, 460.

Bedson, S. P. (1936). Brit. J. exp. Path., 17, 109.

Dulaney, A. D., and Packer, H. (1947). J. Immunol., 55, 53.

Dulaney, A. D., and Packer, H. (1947). J. Imm

and Gordon, F. B. (1944). Proc. Soc. exp. Biol. Med., 56, 159. Landau, H. D. (1946). J. Path. Bact., 58, 568.

Nigg, C., Hilleman, M. R., and Bowser, B. M. (1946). J. Immunol., $53,259$.

Pollard, M., and Witka, T. M. (1947). Texas Rep. Biol. Med., 5, 288. Rake, G., Eaton, M. D., and Shaffer, M. F. (1941). Proc. Soc. exp. Biol. Med., 48, 528.,

and Jones, H. P. (1944). J. exp. Med., 79, 463.

St. John, E., and Gordon, F. B. (1947). J. infect. Dis., 80, 297. Smadel, J. E., Wertman, K., and Reagan, R. L. (1943). Proc. Soc. exp. Biol. Med., 54, 70.

Wall, M. J. (1946). J. Immunol., 54, 59. 